\title{
POOLING AGREEMENTS AMONG STOCKHOLDERS
}

So much of the business of the world is done through the agency of corporations, and so many people are stockholders in these institutions, that few legal questions are of interest to a greater number of persons than those relating to the ownership of stock and corporate control by stockholders.

While it is true that the directors control and manage the corporation's business, free from dictation by the shareholders, the power to determine who shall be directors rests with the shareholders and they may by their votes annually change the directorate if they so desire. So that the policy of the corporation may and should be determined by the shareholders electing to the directorship those who stand for the views of a majority of the owners, or stockholders. For, however distinct may be the corporation from the stockholders who compose it, they are the parties most directly interested in its affairs. They have furnished the funds for its working capital, are entitled to whatever dividends are declared from its profits, or sustain to the extent of this capital, whatever loss may come from its reverses, and upon its dissolution they succeed to all its property.

Since the principle of majority control applies to corporate affairs and majorities are determined not by the number of individuals or shareholders, but by the number of shares of stock voted, one person may be able to outvote all other members of the corporation, and thus enforce his plan of management or mismanagement, over the combined objections of all others.

The subject of voting trusts within a single corporation has not received from the courts as much attention as have those agreements for the combination of different corporations and partnerships engaged in the same business. The two agreements have little similarity, are for purposes entirely different, and are not governed by the same rules of law. The one is a combination of stockholders only for the purpose of managing the affairs of a single corporation; the other has for its purpose the combining of competing institutions with the power if not the purpose of increasing the price of the commodity produced. For this reason alone the latter is held to be against public policy and void as a 
contract. But in the voting trust there is no combination which in itself is against public policy nor which violates any law.

This power of control by a bare majority of stock is of greater importance than at first may appear, for it can be used to the corporation's detriment as well as for its good. So long as those who are in control keep within the law of corporations, there is no way by which the minority can interfere to prevent what may seem to be extravagant and destructive methods.

The profits may be absorbed in large salaries of officers and directors, all of whom may be selected from the majority shareholders, thus making the stock of the majority valuable, while that of the minority could not be sold upon the market, simply because it is minority stock. Or if the profits are not thus absorbed the directors, at the dictate of the majority, all of whom may be holding offices with munificent salaries, may reasonably invest such extra profits in enlarging the business, instead of declaring dividends. Numerous methods may be adopted by the majority, keeping entirely within their legal rights, by which the capital of the minority shareholders is made profitable only to those in control. And if, emboldened by success, they overstep the boundary of legal rights and withhold from the minority what is justly theirs, or take from the corporation that to which they are not legally entitled, a stockholder may well hesitate to begin proceedings to correct the evil. Theoretically, the loss is not his, but is that of the corporation. The right of action belongs to it and not to him. Since it is under the control of the wrong-doers, they, of course, will not permit suit to be conducted in its name. By showing these facts the shareholder may sue in his own name, but if he wins after annoying tedious litigation, the amount recovered inures only indirectly to his benefit, for it belongs not to him but to the corporation, and must be covered back into its treasury, to be again managed by those in control.

It should not be assumed, however, that this power of majority control will be used to the detriment of either the corporation or the other shareholders. It is, in fact, rarely so exercised; but on the other hand it will be found that corporate business, like that of the individual, is usually conducted on a basis of honesty and fair dealing. As a rule, those who place themselves in control of corporate affairs do so for the purpose of giving all who are interested equal benefits, faithfully executing the trust imposed upon them. The power they hold is all the 
more important because it can be used in excluding from the directorship those who would wreck such institutions for private gain.

Because of the importance of majority control, many schemes have been devised by ingenious lawyers to organize a voting majority of shareholders for the purpose of temporarily or permanently managing corporate affairs. These contracts have usually proven unsatisfactory to one or more of the parties interested in them, and have therefore in various ways come into the courts, to be tried and their legality tested. Many of them have been condemned as illegal, because against public policy. Others have been held not to be against public policy, but have been adjudged voidable at the election of any party to them. Still others have been held valid and binding upon all parties affected by them, and courts have enforced them according to their terms.

But it is believed that no contract of this character has yet been passed upon by the courts where the vital purpose of such an agreement was tested by litigation. For the prime object which stockholders, entering into any such arrangement, have in view is to form a combination which cannot be overthrown by any of the parties to it - one which will remain intact for the period agreed upon, although some of the parties thereto may be tempted beyond that which they are able to bear, by a combined minority offering them many times the real value of their stock for the purpose of securing to themselves the balance of power. In short, the most important question touching this whole matter is: Can a voting trust be so formed by a majority of shareholders that its continued existence may be relied upon by those who enter into it? Or, do the dangers of illegality, voidability and liability to breach by some of its members, attach to all such combinations?

It will be important to examine the different kinds of voting agreements which have been passed upon by the courts. They may be divided into at least three classes above indicated, namely, void, voidable and valid.

\section{VoId Agreements.}

Where the purpose of such agreements is illegal, the courts promptly pronounce them invalid. To determine their validity, the object which governed the shareholders in forming the contract will be looked into by the courts. 
So where the agreement contained a provision whereby one of the parties thereto should be continuously employed at a specified salary as general manager of the corporation, it was held invalid.' So where such contract is made with another corporation to hold and vote the stock, which power is ultra vires the holding corporation $;^{2}$ so in any case where the agreement amounts simply to a contract by the shareholder to sell or barter away his right to vote. $^{3}$ The courts say that a sale by a shareholder in such case is against public policy and illegal, upon the same theory that a sale by a citizen of his vote at a municipal election, or a sale by a director of a corporation of his vote in a directors' meeting is illegal. Other cases hold clearly that any contract is void in which the voting power of the shareholder is separated from the title to the stock and it will not be enforced by the courts.

The Shepaug Voting Trust Cases" bear directly on this phase of the subject. Here a syndicate secured a majority of the stock of the Shepaug Railroad Company, placing the same in a voting trust for a period of five years. A certain trust company was made trustee of this stock for the purpose of voting it as directed by a committee appointed by the syndicate. It was shown that the syndicate by this arrangement not only secured the control of the railway company, but that there was a secret purpose to make for themselves a profit out of certain construction contracts which they were able to secure. The court held the whole contract void for this reason.

In Kreissl v. Distilling Co. of America, 6I N. J. Eq., 5, the following rule touching the illegality of such combinations is adopted: "If stockholders combine $* * *$ to entrust and confide to others the formulation and execution of a plan for the management of the affairs of the corporation, and exclude themselves by acts made and attempted to be made irrevocable for a fixed period, from the exercise of judgment thereon, or if they

${ }^{1}$ Cohen v. Russell, 48 N. J. Eq., 208; Gage v. Fisher, 5 N. D., 297.

2 Hafer v. Ry. Co., Jezuctt et al., i4 Weekly Law Bul. (Ohio), 68.

${ }^{3}$ Guernsey v. Cook, 120 Mass., 50I; Noel v. Drake, 28 Kans., 265; Woodruff v. Wentworth, 133 Mass., 309; Freon v. Carriage Co., 43 Ohio St., 38; West v. Camden, 135 U. S., 513.

White v. Thomas Inflatable Tire Co., 52 N. J. Eq., I78; Shepaug Voting Trust Cases, 60 Conn., 576; Cone v. Russell, 3 Dick. Chancery Rep., 208.

60 Conn., 553; Harvey v. Improvement Co., II8 N. C., 693; Moses v. Scott, 84 Ala., 608. 
reserve to themselves any benefit to be derived from such plan to the exclusion of other stockholders who do not come into the combination, then such combination and the acts done to effecturate it are contrary to public policy, and other stockholders have a right to the interposition of a court of equity to prevent its being put into operation."

While the courts do not all agree that an irrevocable proxy given by a shareholder to another to vote his stock for a fixed period is invalid as against public policy many do so hold, upon the theory that each stockholder owes to all others the duty of exercising the right to vote in all matters relating to the welfare of the corporation, which means, necessarily, the welfare of all the stockholders. This privilege and duty creates a fiduciary relationship between shareholders which cannot be irrevocably transferred to some one else.

When a voting contract contains some provision which is against public policy, it vitiates and makes void the entire agreement, and the court will for this reason set aside the whole contract. $^{\mathbf{B}}$ Many other examples might be cited where courts have held these contracts illegal, but the foregoing will illustrate this class.

\section{Voidable Agreements.}

Those agreements may be regarded as voidable in which parties thereto may continue their execution, against the will of other persons who are interested but not parties to the agreements, or may at any time withdraw therefrom. They are not against public policy but are not enforceable contracts. In this class, the more recent cases seem to place so-called irrevocable proxies and combinations which for a definite period, separate the voting power from the ownership of the stock, though as above indicated the courts are in conflict here.

Where shareholders in a corporation place their stock in the hands of trustees with power to vote it, and a clause in the contract declares this power to be irrevocable, even those courts which do not regard the contract as violating pubilc policy, hold it voidable at the will of the parties to it. The rule generally

'Gage v. Fisher, supra; Wieber v. Stocpel, 82 Mich., 344; Noys v. Marsh, 123 Mass., 286. 
followed in such cases is well stated in Griffith $v$. Jewett, ${ }^{7}$ as follows: "The owners of these trust certificates are equitable owners of the shares of stock which they represent, and being such the individual right to vote upon the stock pertains to them. They may permit the trustees as holders of the legal title to vote in their stead if they choose, but when they elect to exercise the power themselves, the law will not permit the trustees to refuse it to them."

This rule meets the approval of one's judgment. It permits one to appoint another to vote for him so long as there is no fraud or injury to anyone else intended; but as in the case of an appointment of an agent to perform other acts, the agency is at any time revocable by the principal.

Since stockholders have the power to combine in an election, with a view of placing in office certain persons, for the benefit of the corporation, there is no good reason why this combination for lawful objects, and the preservation of the company's best interests should not be continued indefinitely. And for the better accomplishment of this purpose shareholders should be permitted to place their stock in hands of trustees so long as all agree to do so. $^{8}$

\section{Valid Agreements.}

A number of cases have arisen where for the best interests of the corporation involved, agreements have been entered into by various shareholders to place their stock in trustees' hands to be voted as directed by interested persons, such as creditors, who in consideration of this arrangement refrain from pressing their claims.

In other cases capital was furnished to aid corporations in financial straits, on condition that the control of corporate affairs should be thus given over to a committee for a definite period. ${ }^{9}$

While in these cases the voting power is separated from the title to the stock, they are distinguished from those where the

7 Weekly Law Bulletin (Ohio), $4 \mathrm{Ig}$.

${ }^{8}$ Railway Co. et al. v. State ex rel., 49 Ohio St., 668; Vanderbilt v. Bennett, $6 \mathrm{~Pa}$. County Court Rep., I93; Chapman v. Bates, 6r N. J. Eq., 658; Fisher v. Bush, 35 Hun., (N. Y.) 64I; Moses v. Scott, 84 Ala., 608; Woodruff v. Dubuque Co., 30 Fed. Rep., 9r; People ex rel. Union Ins. Co. v. Nash et al., III N. Y., 3Io.

-Mobile R. R. Co. v. Nicholas, 98 Ala., 92 ; Havemeyer v. Havemeyer, II Jones \& S., 506. 
sale of the voting power was involved, in that the purpose was to aid the corporation without intending an injury to anyone. The power to vote is coupled with an interest.

In Mobile R. R. Co. v. Nicholas, supra, an agreement of this character was involved. The company had defaulted in some of its interest payments and was financially embarrassed. An agreement between its creditors, some of whom had already begun foreclosure proceedings, resulted in a discontinuance of the litigation, upon condition that certain financial aid should be secured by a number of the stockholders placing their stock in the hands of a trust company with an irrevocable power of attorney to vote the stock so long as the debentures of the company remained unpaid.

This arrangement having been completed the trust company took possession of and voted the stock for a number of years. Later some of the owners of the stock claimed the right, personally, to vote thereon, and attempted by injunction to prevent the trust company from doing so, on the theory that their contract was illegal as against public policy. The court refused to sustain this contention and said that "in determining the validity of an agreement which provides for the vesting of the voting power in a person other than the stockholder, regard should be had to the condition of the parties, the purposes to be accomplished, the consideration of the undertaking, interests which have been surrendered, rights acquired and the consequences to result."

A number of recent cases have gone still farther, and hold that when there is a pooling contract, based upon sufficient consideration, in which the voting power is separated from the ownership of the stock irrevocably, for a fixed period of time, for proper purposes, such contract is valid and will be enforced. ${ }^{10}$ The tendency of the courts is now to uphold such contracts when they are based upon a sufficient consideration, whether the prime object is to aid the corporation or not.

By an act of April 16, 1906, the Legislature of New York made provision for stockholders to vest their voting power for a period not exceeding five years in other persons, without transferring the title of the stock, and in the same law prohibited the selling of votes or proxies by shareholders.

${ }^{10}$ Smith et al. v. San Francisco Ry. Co. et al., II5 Cal., 584; Brightman v. Bates, 175 Mass., I05; Mobile Ry. Co. v. Nicholas, 98 Ala., 92 ; Faulds v. Yates, 57 III., $4 \mathrm{I} 6$. 
But there is nothing to prevent a shareholder who has made such contract, however valid, from violating it, and subjecting himself to damages for its breach. One owning ten shares may thus hold the power to give to one, or to another group of shareholders the majority, by selling to them his stock, thereby giving them control of the corporation. Damages which could be recovered for such breach would probably be nominal only, or if substantial, could not compensate for the loss of control of the corporate affairs, and the resultant depreciation of values in the stock of those who thereby lost the majority.

-To obviate this condition, it is said in Harvey $v$. Linville Improvement Co., II8 N. C., 693, 54 Amer. St. Rep., 749, that "various devices have been resorted to for the purpose of so tying up the stock that no one of the parties to the 'pool' or combination can break the agreement." The court then points out the numerous plans which have been tried and defeated.

Among those mentioned are irrevocable proxies, which were pronounced revocable $;^{11}$ the transfer of stock to trustees, and rcceiving instead, trust certificates. But the court said that any holder of a trust certificate could surrender it, and demand the return of his stock. ${ }^{12}$

In another scheme the parties contracted together not to dispose of their stock for a definite time, or only to specified persons, or to purchasers acceptable to all; but it was determined that any party might sell his stock when and to whom he pleased.13 Again it was attempted to restrict the sale of the stock by by-laws, but this was held illegal. ${ }^{14}$ And a rule would be unlawful which provided that the purchaser of a share of stock should be entitled to dividends but not permitterl to vote where the sale of stock was in violation of the agreement.

Wherever one corporation is permitted to own stock in another corporation without restriction, an effective plan for pooling stock can be easily devised. The title of a majority of stock can be taken by the holding company to be voted by the directors

11 Woodruff v. Dubuque, 30 Fed. Rep., 91.

12 Hafer v. New York etc., R. R. Co., 44 Wcekly Law Bulletis (Ohio), 68; Vanderbilt v. Bennett, 2 Ry. \& ${ }^{\circ}$ Corp. L. J., 409.

${ }_{13}$ Moses v. Scott, 4 Southern Rep. (Ala.), 742; Fisher v. Bush, 35 Hun. (N. Y.), 642 ; Williams v. Montgomery, 68 Hun. (N. Y.), 4 I6.

14 Morgan v. Struthers, I3I U. S., 246; Fechlieimer v. Nat'l Exc. Bank, 79 Va., 80; Orr v. Bigelow, I4 N. Y., 556; In re Klaus, 29 N. W. Rep. (Ala.), 582 . 
of that company. So long as those who favor holding the stock and voting it are directors the control will be easily maintained. But the stockholders of the holding company may change, and elect directors who are not in accord with the idea of thus controlling one corporation by another. Besides, there are only a few States in which one corporation can legally purchase and hold the stock of another. Generally such purchase would be ultra vires and could be prevented by the State or the shareholders of the purchasing corporation. This method is also quite cumbersome and has not proven popular.

The most feasible plan for creating the desired voting trust is by means of a common law joint stock company. This kind of an organization requires no legislative sanction for either its existence or powers. It is formed by contract of the parties interested, and the measure of their rights and liabilities will be found in the articles of association. It is of the nature both of a partnership and a corporation, but is different from either. Stock may be issued, held and transferred as in corporations. The sale of a share by one of the company will not, if so provided, work a dissolution of the association, as would the sale of a partner's interest in a partnership. The articles may provide, however, that the purchaser of such share of stock shall not become, by such purchase, a member of the association, unless acceptable to all the other members. Or he may be given a right in the property, income, or dividends without the right to vote, or to in any way participate in the management of the company's affairs. This restriction could not legally be imposed upon a stockholder in a corporation. Hence, the joint stock company may be utilized to greater advantage than could a corporation. It is not beyond the powers of a joint stock company to purchase, hold and yote the stock of corporations. Such an association, like a partnership, may do any legal business which may be done by individuals, and may be formed for any legitimate purpose. There could, apparently, be no objection, therefore, to the holders of a majority of the stock in any corporation, forming a common law joint stock company for the purpose of holding and voting the corporate stock. It could be sold and transferred to the joint stock company in consideration of certificates of shares in the joint stock company, issued in lieu of the corporate stock, to the former holders thereof. There would be no separation of the ownership and voting power of the corporate stock, since the 
joint stock company would be both owner and voter of such stock. It would always be voted by the directors of the joint stock company in such way as to control the affairs of the corporation. The clause limiting the purchaser's rights upon a sale of shares in the joint stock company would prevent new shareholders, or outsiders, securing control of the joint stock company, or transferring any power to the minority shareholders in the corporation. This would seem to present a plan by which the majority shareholders in a corporation can safely combine for its control.

While, so far as the writer knows, it has never been tested by the courts, the principles involved have, in a case or two, been approved, where a voting trust was not concerned.

A question somewhat similar to this was involved in Harper $v$. Raymond, 3 Bosworth Rep., 29 (N. Y.). There a common law joint stock company had been formed for the purpose of publishing the New York Times. The articles of association consist of seven items, the sixth of which relates to the point under consideration and reads as follows:

"Each of the parties hereto shall have the right to sell any portion of his shares of stock; but before selling the same to any other person, he shall offer the same to the association, giving them the refusal thereof for ten days. But no sale of any such shares shall give to the purchaser thereof any right to interfere in the conduct, management or affairs of said newspaper; or either of them; and no such purchaser shall acquire any interest whatever in the profits of said papers till he shall have received a certificate or scrip for his shares, signed by all the parties hereto, and duly registered in a book to be kept for that purpose, which scrip shall always express from whom such shares were purchased, and shall certify that the holder of said scrip takes the same with notice of and subject to the articles of association between the parties hereto, and is entitled to participate only in that portion of the profits which may be assigned to the party so selling to said purchaser; and shall not be entitled to any voice or agency whatever in the conduct, control, management or affairs of said company or of said newspapers."

In construing this article the court held that a purchaser of shares of stock who had not complied with the articles or been admitted to membership of the association in accordance with the articles, did not become a member, and could not be intruded upon the association. The sale of the shares in the attempt by one of the members to transfer his interest to a stranger, did not work a dissolution of the partnership or joint stock company, but 
only gave to such purchaser an equitable right to draw his portion of dividends, until such company was dissolved. He would then share with the other owners in a distribution of the company's assets. ${ }^{15}$

It is submitted that this plan embodies all the advantages which have been sought by the numerous devices heretofore attempted, so many of which for various reasons, failed to accomplish the purpose for which they were promoted.

Dean of Cincinnati Law School.

William P. Rogers.

${ }^{15}$ This theory is sustained by Tatam $v$. Williams, 3 Hare's Rep., 347. 